\title{
Projeto Geoparque na Bacia do Rio Corumbataí: um estudo sobre modelos jurídicos para a constituição de uma Associação gestora.
}

\section{Cinthia da Silva Zacarão*, Luciana Cordeiro de Souza Fernandes.}

\section{Resumo}

O presente projeto de pesquisa visa realizar um levantamento dos modelos jurídicos para criação de uma Associação civil - gestora, elencando suas diferenças e apontando para um modelo a ser levado ao Projeto Geopark Corumbataí. Tal projeto situa-se na Bacia do rio Corumbataí, uma sub-bacia do rio Piracicaba, a qual é composta por oito municípios localizados no interior de São Paulo, sendo eles: Analândia, Charqueada, Corumbataí, Ipeúna, Itirapina, Piracicaba, Rio Claro e Santa Gertrudes.

Palavras-chave: Geopark UNESCO; Gestão sustentável; administração turismo.

\section{Introdução}

O projeto Geopark Corumbataí, foco de análise deste projeto, situa-se na Bacio do Rio Corumbataí, uma subbacia do Rio Piracicaba. A escolha desta Bacia se deve ao fato de ser uma área territorial com limites claramente definidos, que incluiu notável patrimônio geológico.

A região possui grande potencial de crescimento em relação ao turismo, ainda sem muita exploração e, mesmo que a equipe do Projeto Geopark Corumbataí esteja em contato com os oito municípios, ainda não há uma fluente comunicação entre eles e os principais objetivos do projeto Geopark Corumbataí, pois não há uma unidade gestora capaz de articular a intercomunicação. Desta forma, é necessário a constituição jurídica de uma associação gestora administradora e interlocutora para os 8 municípios da Bacia - como um meio legal para facilitar a comunicação, bem como para buscar recursos para as obras e atividades necessárias para a constituição do Geopark.

Este estudo tem a preocupação de detalhar os modelos jurídicos de Direito Civil, assim como apresentar a natureza jurídica de Associações geoparks existentes e sugerir a melhor opção para o projeto. Para tal, foi realizado um levantamento comparativo entre alguns dos Geoparks já constituídos e reconhecidos pela UNESCO.

\section{Resultados e Discussão}

Para fim de comparação, foram pesquisados os Geoparks: Araripe, localizado no Ceará - Brasil; Arouca, localizado em Arouca - Portugal; Gruta Del Palácio, localizado em Flores - Uruguai; e, Açores, localizado no arquipélago dos Açores - Portugal. Em todos os Geoparks pesquisados verificou-se que a gestão em comum com a sociedade é a melhor maneira de alcançar o seu sucesso, isso porque o conceito de Geopark traz consigo a participação da comunidade, que possui em sua composição pessoas naturais e pessoas jurídicas. Desta forma, tais Associações podem adotar modelos jurídicos diversos, com natureza jurídica tanto de direito privado como de direito público, composta pela comunidade e poder público, no último caso. No único geoparque brasileiro - o Araripe - a Associação é de direito público, sendo regida pelas regras do Direito Administrativo. Todavia, esta escolha demonstrou dificuldades na gestão cotidiana deste geoparque, em razão dos processos licitatórios.

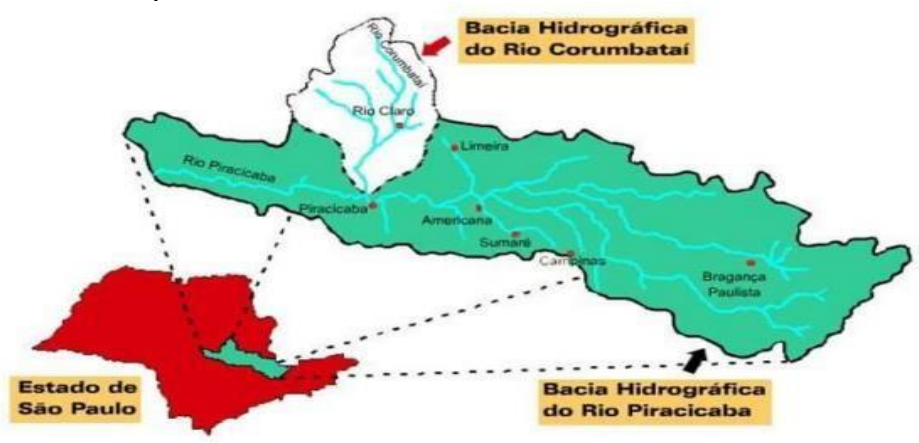

Figura 1. Destaque da bacia do Corumbataí Fonte: Geopark Corumbataí, 2018

\section{Conclusões}

Visando uma gestão mais eficiente e uma comunicação fluida entre os atores envolvidos, tem-se no direito privado o melhor meio para se constituir uma associação para o Geopark Corumbataí.

A Associação de direito privado permitirá que quaisquer pessoas, dos 8 municípios, sejam elas pessoas naturais ou jurídicas, se unam, constituindo uma pessoa jurídica de direito privado e desenvolvendo ações para a gestão do Geopark, sem a necessidade dos processos licitatórios em sua atuação gestora.

\section{Agradecimentos}

Agradeço ao SAE/UNICAMP, ao grupo de pesquisa CNPq (Aquageo Ambiente Legal) e à minha orientadora, a Professora Dr ${ }^{\mathrm{a}}$. Luciana Cordeiro de Souza Fernandes.

\begin{tabular}{lcc}
\hline AÇORES & GEOPARK. & Disponível \\
$<$ http://www.azoresgeopark.com/index.php>. Acesso em 08 out. 2018.
\end{tabular}

em:

ARARIPE GEOPARK. Disponível em: <http://geoparkararipe.urca.br>. Acesso em 08 jul. 2019.

AROUCA GEOPARK. Disponível em: <http://aroucageopark.pt/pt/>. Acesso em 22 fev. 2019.

BRASIL. Código Civil Brasileiro. São Paulo: Saraiva, 2019.

GRUTAS DEL PALÁCIO GEOPARK. Disponível em:

<http://geoparque.uy/index.php>. Acesso em 22 fev. 2019. PROJETO GEOPARK CORUMBATAÍl Disponível em: <https://geoparkcorumbatai.com.br/> Acesso em: 16 abr. 2018

UNESCO CIÊNCIAS DA TERRA (2018). O que é um Geoparque Global da UNESCO? Disponível em: <http://www.unesco.org/new/fr/naturalsciences/environment/earth-sciences/unesco-global-geopark s/frequently-askedquestions/what-is-a-unesco-global-geopark/>. Acesso em: 11 abr. 2018 